gases for liquids or vice versa. The conflicting requirements of the laws of similitude complicate the design of experiments, and a plea was made for the publication of more experimental data to provide a basis for evolution of rules to govern the 'scaling-up' of model performance. Increases in the duty required to bo undertaken by modern hydraulic machinery have caused a marked increase in the incidence of cavitation, and Mr. Robinson diseussed the influence of the properties of the liquid itself and the presence of nuclei on cavity collapse and noise. Methods for estimating flow losses with non-Newtonian liquids require development. The pumping of raw peat and measurement of the flow of blood to and from the human heart provoked a lively discussion.

Lubrication has been defined as the reduction of friction and wear between rubbing surfaces by interpolation of substances which offer resistance to the normal forces pressing the surfaces into contact and yet are capable of being deformed easily in a tangential direction. It is obvious that the rheological properties of lubricants are of interest to engineers concerned with running machinery, and Dr. F. T. Barwell (East Kilbride), in a contribution on lubrication from the rheological point of view, outlined some of the considerations governing boundary and hydrodynamic lubrication. Further understanding of the mechanism of wear is dependent, among other things, on an understanding of the rheological behaviour of material in the surface regions of components suffering damage. Examples were given of those forms of wear known as abrasion, scuffing and pitting, and the potentialities of radioactive tracer methods for the study of wear were discussed.

\section{THE ROYAL NETHERLANDS METEOROLOGICAL INSTITUTE (1854-1954)}

T

HIS decade is one of centenaries in the meteorological world, for official meteorological activities started in many countries around 1850. The Royal Netherlands Meteorological Institute, now at De Bilt near the town of Utrecht, was established in 1854 and colebrated its centenary this year on January 31. As part of the celebrations, a substantial memorial volume has been prepared*, in which the history of the Institute is portrayed in word and image.

Meteorology in the Netherlands did not start in 1854; there are many signs of earlier activity in the form of long series of observations, admirably compiled by Labrijn. As everywhere else in the world, these observations were made at universities, or by organizations and persons especially interested in meteorology; and looking at the state of affairs in 1854, one should realize that the famous American naval officer, Maury, prior to that year, had already collected many meteorological observations from oceanic areas.

In the Netherlands it was important for the development of the subject that Buys Ballot, chemist, mineralogist, mathematician and physicist, became fascinated by meteorological problems, and that he, in his position as university professor, created an

* Koninklijk Nederlands Meteorologisch Instituut 1354-1954. Pp. $469+74$ flgs. +4 coloured plates. ('s-Gravenhage: Staatsdrukkerij en Uitgeversbedrijf, 1954.) observatory in Utrecht. Late in 1853 Buys Ballot convinced the Government that "there was a future in the establishment of a Meteorological Institute" and early in 1854 his observatory was converted into the Koninklijk Nederlands Meteorologisch Instituut. Buys Ballot was the first director of the Institute and aimed very high. Translated freely, his programme was formulated by the words: "As a result of the methods we have adopted-namely, to collect observations from some well-selected points abroad and to study the deviations from the normals at these points - the Institute pursues a higher object than any other existing institute. Day after day it deals with the most important questions in meteorology, the solution of which was already some years ago vaguely indicated by Dove for monthly periods. Utrecht will become the central observatory for Europe. Already nowadays the weather and its changes over the greater part of Western Europe are being closely followed and studied".

The early period of Buys Ballot's directorship was one of great activity. It was the time of Dove in Germany, Espy in the United States, FitzRoy in Britain and LeVerrier in France. It was also the time in which meteorologists suddenly became aware that weather forecasting might develop into a reality as a result of the invention of the electric telegraph. Great discoveries were made : Buys Ballot announced one of them in the form of four propositions during a meeting of the Netherlands Academy of Sciences (October 3, 1857), and it was on the basis of these four propositions that later on the famous wind law of Buys Ballot was formulated. Weather maps, though rather primitive, were drawn by Buys Ballot on a routine basis, and a gale warning service was established in 1864. Internationally minded as he was, Buys Ballot copied the system of signals already in use in Britain; but when the British service was discontinued in 1866, he felt free to develop the 'aëroclinoscope', a new design to indicate forthcoming gales to sailors. The aëroclinoscope was a signal post, which showed the direction and value of the pressure gradient over the Netherlands. Its indications had therefore to be interpreted by the users, who had to have a thorough idea of Buys Ballot's law. This might be one of the reasons why the Dutch merchant marine became so early thoroughly interested in meteorology and assisted the Institute in building up an enormous amount of material, gathered from almost every ocean.

It is worth noting that Buys Ballot needed continuous registration of the pressure values at several stations in order to be able to follow the gradients closely. The first electric telerecorders, precursors of our radiosondes, were then developed and for some time serious efforts were made to record at Utrecht the pressure values at Flushing during the night hours. The technical difficulties appeared to be very great, and finally the efforts were given up. It is still, however, customary in the Dutch synoptic service to compute the pressure gradient in various triangles over the Netherlands on an hourly routine basis.

Buys Ballot needed uniform observations for the successful realization of his programme. The wellknown international congress in Brussels (1853), which was initiated by Maury, created a certain uniformity in maritime meteorology; over land, however, observations were made at different times, with different instruments in varying exposure. The difficulties resulting from the lack of generally 
accepted rules inspired Buys Ballot to write a treatise entitled "Prière à tous ceux qui veulent bien de la météorologie" (1856). But it was only sixteen years later that Buys Ballot opened the first international meteorological congress at Leipzig and became. the first president of the International Meteorological Committee and the real father of international meteorology. Dutch meteorologists continued to play important parts in the international meteorological world; Van Everdingen guided the International Meteorological Organization during 1923-35, and Cannegieter was the first chief of the permanent secretariat of that Organization.

The Institute lost its great leader in 1890, and with his decease an era of steady development came to an end. Meteorology entered, not only in the Netherlands but also elsewhere, a rather dull period which started with "the disappointment of the nineties". New horizons were opened around 1910, with the beginning of upper-air observations. Van Everdingen, director since 1905, started his activities as extra-ordinary professor at the University of Utrecht with a lecture entitled "The Third Dimension in Meteorology". A theodolite for recording the projections of pilot balloon-tracks was developed, kite ascents were made, and many Dutch meteorologists had licences as free-balloon pilots. Cannegieter was the first who experimented with aeroplanes as meteorograph-carriers, and the regularity of the Netherlands upper-air ascents became known all over the world. When a new field was opened with the introduction of the radiosonde, Cannegieter used the instrument on an expedition to the Azores, from where no upper-air information had previously been obtained, and also in Iceland during the second Polar Year.

When Van Everdingen took the reins, the Institute, which had moved from Utrecht to De Bilt in 1897, consisted already of five divisions. It was then, and still is, really a geophysical institute, the activities of which are not limited solely to meteorology. With the development of the geophysical sciences during the course of the past half-century, the divisions slightly changed their names, but there are still those of forecasting (now combined with aeronautical meteorology), climatology (now combined with agricultural meteorology), maritime meteorology (now combined with oceanography), seismology and magnetism (now also deeply involved in ionospheric research) and finally a general service division (administration, library, workshop and instrument development). Each division is headed by a director (a specialist in his own field), and in Van Everdingen's time the director in chief was still an all-round meteorologist.

Cannegieter guided the Institute through the unhappy period of the Second World War, when forecasting for the general public and for aeronauties was curtailed, and synoptic and aerological observations were totally stopped. In spite of all material and other difficulties, the war period provided some dividends, as the synoptic staff took part in an extensive magnetic survey of the Netherlands, thorough plans could be made for future development and serious scientific investigations improved the knowledge of the forecasters who were perforce idle during this period.

Thus came the post-war period, with its stormy development in the Institute's activities and the enlargement of its field of action. Cannegieter, who had already passed the retiring age, was succeeded by Vening Meinesz, a geophysicist of renown who had already long relations with the Institute, where, among others, his apparatus for gravity measurements at sea had been built. From 89 men (24 scientists) in 1945 the personnel jumped to 345 (73 scientists) in 1954. The greatest growth took place between 1945 and 1950. It was no longer feasible to house all the workers stationed at $\mathrm{De}$ Bilt in the old building. Offices were spread all over the village. The disadvantages of this involuntary decentralization were felt almost daily. Vening Meinesz's ambitions to bring the Institute again under one roof were, in spite of all difficulties, realized in 1953, when new wings to the old building came into use. The floor space of approximately $1,000 \mathrm{~m} .{ }^{2}$ was increased to $3,500 \mathrm{m.}^{2}$, and, in addition, a plot of 2 hectares was joined to the gardens, sufficiently large for investigations in the field of agricultural meteorology and for the launching of radiosondes in spite of the fact that the aerologists are close neighbours of the ionospheric transmitter with its high antennæ.

Vening Meinesz found himself too much absorbed in administrative duties and returned to science again in 1951, at the moment when, according to his views, the staff was sufficiently large to deal with its practical and scientific tasks, and when his plans for the extension of the premises were accepted by the Government. He was succeeded by the present director, C. J. Warners, a former Secretary of State in the Netherlands East Indies.

The Royal Netherlands Meteorological Institute is an entity in the economic life of the Netherlands, not only because of its forecasts for the general public, agriculture and horticulture, fisheries, shipping and aviation, but also because of its activities in so many other fields. It has relations with agricultural research, through an active group of agricultural meteorologists. With those interested in the water bolance of earth and atmosphere, it studies evaporation and related processes. A group of statistical workers has already solved many practical problems. The maritime meteorologists, up to now engaged in the construction of the atlases for mariners, have diverted their interests in a scientific direction. Oceanographers pay much attention to high tides and storm surges in the North Sea, but do not neglect other problems of a local nature. New ideas about microseisms have developed in the seismology division, and the telegraph authorities keep close contact with the workers in the fields of magnetism and ionospheric research. These are but a selection of the many topics in which the Institute is interested, all of which are faithfully recorded in the recent centenary volume. W. BLEEKER

\section{OBITUARY}

\section{Mr. F. Morley Colebrook, O.B.E.}

During his thirty-three years service on the scientific staff of the National Physical Laboratory, Mr. F. M. Colebrook, who died on June 21, played a major part in the development of the Radio Division from its birth as a section of the Electricity Division, and more recently became the head of the newly formed Electronics Section.

Colebrook was born in March 1893 and studied science at Birkbeck College, University of London. After service in the First World War, he continued his 